\title{
Binding of magnesium and calcium in the contents of the small intestine of the calf
}

\author{
BY R. H. SMITH AND A. B. MCALLAN \\ National Institute for Research in Dairying, Shinfield, Reading
}

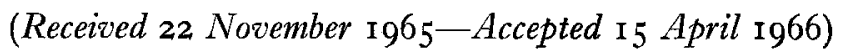

\begin{abstract}
I. In ileal contents from differently fed ruminating calves, examined under conditions approximating to those obtaining in vivo, $34-74 \%$ of the magnesium and $63-93 \%$ of the calcium were non-ultrafilterable. The binding was shown to be due to at least two processes, one depending on the presence of phosphate, the other not. 2. Considerable non-phosphate binding occurred in samples adjusted in vitro to $\mathrm{pH} 5.5$ and above. The binding material was probably not a single substance but the bound forms of both $\mathrm{Mg}$ and $\mathrm{Ca}$ were, at least partly, in equilibrium with the soluble forms, and some competition between the two metals occurred. Thus in any one sample the extent of binding for either metal was infuenced by the concentration of both. With normal concentrations it was estimated that, in the ileum, about one-third of the $\mathrm{Mg}$ and half of the $\mathrm{Ca}$ was bound in this way, irrespective of whether pasture or one of a variety of stall diets was given. 3. Samples adjusted to about $\mathrm{pH} 6.5$ and above (in vivo ileum $\mathrm{pH}$ was about $7 \cdot 4-7 \cdot 9$ ) showed further precipitation of $\mathrm{Ca}$ and $\mathrm{Mg}$ to an extent which partly depended on the concentration of inorganic phosphate. Ca precipitation appeared to be mainly controlled by the concentration of $\mathrm{Ca}$ and inorganic phosphate but for $\mathrm{Mg}$ the precipitation depended also on the presence of factors other than $\mathrm{Mg}$ and inorganic phosphate. One such factor found to be present was the ammonium ion, but its practical importance is uncertain. 4. Ileal contents from milk-fed calves showed considerable non-phosphate binding of $\mathrm{Ca}$ but not of $\mathrm{Mg}$.
\end{abstract}

Evidence from a variety of animals suggests that the small intestine is the main site of magnesium absorption (Field, 1961; Aikawa, 1959; Graham, Caesar \& Burgen, 1960), although Chutkow (1964) reported experiments with rats which he interpreted as showing absorption in the large intestine. Absorption at both these sites appears to occur in very young calves (Smith, r962), but after the first few weeks of age only the small intestine is important. There is no unequivocal evidence to suggest that $\mathrm{Mg}$ is actively transported across the gut wall (discussed by Smith, 1964). For the older milkfed calf, in which the $\mathrm{Mg}$ content of the digesta in the small intestine is probably largely ionic (Smith, 1966), the net amount of dietary Mg absorbed is directly related both to dietary intake (Smith, I959, 1962) and to the time available for absorption from the small intestine (Smith, 1963). It seems reasonable to assume, therefore, that, apart from a small effect from the potential difference across the wall of the small intestine, less than about ${ }_{5} \mathrm{mV}$, blood positive, in the sheep (Scott, 1965 ), the concentration of ionic $\mathrm{Mg}$ in the digesta at the absorption site within the small intestine is the main factor controlling the amount absorbed in a given time. The main absorption site appears to be distal to the duodenum in the sheep (Field, I96I ; Care \& van't Klooster, 1965) and in the non-ruminating calf (our unpublished observation). Thus, to be effective in reducing $\mathrm{Mg}$ availability, any $\mathrm{Mg}$ binding material in the digesta must survive the processes of digestion and absorption occurring before this region is reached and be active under the conditions obtaining there. The amounts of in- 
soluble $\mathrm{Mg}$ in the diet ('Todd, $196 \mathrm{r}$ ) are probably therefore of little significance and the $\mathrm{Mg}$ binding material demonstrated in the sheep abomasum by Storry ( $196 \mathrm{I} b$ ) would not necessarily still be present at the site of effective $\mathrm{Mg}$ absorption. We have therefore chosen to study $\mathrm{Mg}$ binding in the ileum using ultrafilterability as the main index of availability. Ultrafilterable $\mathrm{Mg}$ is not necessarily all ionic but its determination provides a maximum measure of the probable effective $\mathrm{Mg}$ concentration. Nonultrafilterable $\mathrm{Mg}$ would not contribute to the concentration potential on which the absorption of $\mathrm{Mg}$ is presumed to depend, even though it might be 'available' in the sense of being in equilibrium with ionic $\mathrm{Mg}$.

Many of these considerations do not apply to calcium. Ca absorption in the small intestine of the liquid-fed calf is much more efficient than $\mathrm{Mg}$ absorption, particularly with adequate dietary vitamin D (Smith, 1962) and much occurs in the proximal duodenum (our unpublished observation). In vitro experiments with rabbit intestine have shown that active, vitamin $\mathrm{D}$-dependent, $\mathrm{Ca}$ transfer across the gut wall can occur, particularly in the duodenum (Schachter \& Rosen, 1959). Nevertheless, the present work has included a study of $\mathrm{Ca}$ binding mainly because of possible interrelations with $\mathrm{Mg}$.

\section{METHODS}

\section{Animals and feeding}

Friesian bull calves were used and at $5-17$ weeks of age were equipped with reentrant cannulas in the most distal part of the ileum. The cannulas were made of Perspex and were similar to those described previously (Smith, 1962) except that they were only about $3.5 \mathrm{~cm}$ long. In later experiments a disc (about $8 \mathrm{~cm}$ diameter) of nylon net was sewn between the gut and the body wall to reduce the chance of the cannulas coming out. Most collections of ileal effluent from the outgoing cannulas were made more than 5 weeks after the operation; none was made sooner than 2 weeks after.

Some of the calves were denied solid food. They were efficiently muzzled from about I week of age and given 4.401 . milk/day in two feeds. Intake was increased to 6.151 . day from ro weeks of age. A daily mineral supplement containing $0.08 \mathrm{~g}$ iron, $0.0 \mathrm{I} \mathrm{g}$ copper and $0.0 \mathrm{~g}$ manganese was added from 3 weeks of age. Ileal effluent was collected when required between 3 and $7 \mathrm{~h}$ after a morning feed.

Other calves were weaned before 7 weeks of age and then fed on hay, and a normal calf-rearing mixture. The mixture consisted of $47.5 \%$ flaked maize (FM), $24 \%$ bruised oats, $9.5 \%$ extracted decorticated groundnut meal (DCGM), $6 \%$ dried skim milk, $3 \%$ fish meal and $10 \%$ of a mixture of molasses and peat with supplementary vitamins $A$ and D, calcium phosphate, sodium chloride and trace elements. Some experimental collections of ileal effluent were made with the calves on this diet. During the experiments the concentrate mixture supplied $\mathrm{I} \cdot 3-\mathrm{r} \cdot 5 \mathrm{~kg}$ dry matter/day and the hay $0 \cdot 3-\mathrm{r} \cdot 0 \mathrm{~kg}$ dry matter/day. This will be referred to as diet A. Collections were also made when the calves were receiving these amounts of hay but other concentrate mixtures. The basic compositions of the latter (mineral and vitamin supplements were also given) were as follows, the figures being for dry matter consumed/day: diet B, $0.8-0.9 \mathrm{~kg} \mathrm{FM}$ and 


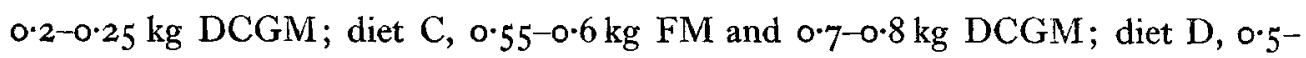
$0.6 \mathrm{~kg} \mathrm{FM}$ and $0.45^{-0.5} \mathrm{~kg}$ wheat-leaf protein (Morrison \& Pirie, $\mathrm{I96 \textrm {r }}$ ); diet $\mathrm{E}, \mathrm{r} \cdot 0-$ $\mathrm{I} \cdot 2 \mathrm{~kg}$ FM. These diets (A-E) provided similar energy intakes (starch equivalent intake about $\mathrm{I} \cdot 0-\mathrm{I} \cdot 4 \mathrm{~kg} /$ day), but widely different crude-protein intakes (from about $\mathrm{O} \cdot \mathrm{I}_{5}$ $\mathrm{kg} /$ day for diet $\mathrm{E}$ to about $0.55 \mathrm{~kg} /$ day for diets $\mathrm{C}$ and D). During other periods one calf received daily $\mathrm{I} \cdot \mathrm{I} \mathrm{kg} \mathrm{FM}$ without hay $(\operatorname{diet} \mathrm{F}$ ) or $0.8-\mathrm{I} \cdot \mathrm{I} \mathrm{kg}$ hay alone (diet G). Other collections were made while the calves were grazing spring pasture. This consisted mainly of $H . r$ ryegrass or timothy and meadow fescue previously fertilized with nitrochalk ( $12 \mathrm{~kg} \mathrm{~N} /$ hectare) and potassium chloride ( $8-16 \mathrm{~kg} \mathrm{~K} / \mathrm{hectare}$ ) and the calves were abruptly turned on to this pasture as soon as adequate growth had started in early spring. Unless otherwise stated, a minimum period of I week was allowed after a dietary change before starting collections. Collections from the stall-fed calves were made during a period of about $2-6 \mathrm{~h}$ after giving food in the morning. Collections from the calves on pasture were made between about II am and $3 \mathrm{pm}$.

\section{Analyses}

$\mathrm{Ca}$ and $\mathrm{Mg}$. These were determined either by the chemical methods described previously (Smith, 1962) or, in later experiments, by a wet ashing technique followed by atomic absorption spectroscopy. For wet ashing about $5 \mathrm{ml}$ of sample, homogenized if necessary, were weighed into a digestion tube $(\mathrm{r} 8 \times 2 \mathrm{~cm})$ and $2 \mathrm{ml}$ conc. $\mathrm{HNO}_{3}$ and $2 \mathrm{ml} \mathrm{HClO}_{4}$ (sp.gr. I.54) added. The mixture was carefully boiled, further amounts of conc. $\mathrm{HNO}_{3}$ being added drop by drop if charring occurred. The boiling was continued until white perchloric acid fumes appeared and the solution was colourless or faintly yellow. The solution was diluted to $25 \mathrm{ml}$ and then further diluted to contain $0.02-0.04 \mathrm{~m}$-moles $\mathrm{Mg} / 1$ or $0.12-0.25 \mathrm{~m}$-moles $\mathrm{Ca} / \mathrm{l}$. Perchloric acid and strontium chloride were added during the final dilution to give concentrations of $0.06 \mathrm{~N}$ and $0.044 \mathrm{M}$ respectively for $\mathrm{Mg}$ determination and $0.24 \mathrm{~N}$ and $0.044 \mathrm{M}$ respectively for $\mathrm{Ca}$ determination. The apparatus and technique were essentially those described by Willis $(1960 a, b)$. Calibration curves were prepared with standard solutions of magnesium or calcium chloride containing the same concentrations of strontium chloride and perchloric acid as the samples. Phosphate, silicate, sodium or potassium respectively added to the solutions in molar concentrations up to $15,2,1000$ and 500 times the $\mathrm{Ca}$ or $\mathrm{Mg}$ concentrations did not interfere in the determinations. Added $\mathrm{Ca}$ did not interfere with $\mathrm{Mg}$ determination or added $\mathrm{Mg}$ with $\mathrm{Ca}$ determination with additions up to twenty times the molar concentrations of the metals being determined. Recoveries of $\mathrm{Mg}$ (seven determinations) and $\mathrm{Ca}$ (fourteen determinations) added to ileal effluent samples were $98 \pm 2$ and $98 \pm \mathrm{r} \%$ respectively.

Inorganic phosphate. This was determined as previously described (Smith, 1966).

Ammonium. Ileal effluent was acidified by adding $0 \cdot 2$ vol. $2 \mathrm{~N}-\mathrm{HCl}$ as soon as it was collected. The mixture was stored at $-14^{\circ}$ and filtered later after thawing. Ammonium concentration was determined in the filtrate by microdiffusion analysis by the method of Conway (1957). 


\section{Examination of calcium, magnesium and phosphate distribution in ileal effluent}

Some samples were collected and ultrafiltered while maintaining conditions as close as possible to those existing in vivo. For this purpose a tube of flexible polyvinylchloride, internal diameter about $\mathrm{I} \mathrm{cm}$ and length about $100 \mathrm{~cm}$, was connected to the outgoing cannula and kept nearly horizontal. Effluent was allowed to flow along this tube with minimum disturbance until the tube was full. About the first Io $\mathrm{ml}$ were allowed to run to waste and the tube was then clipped at the distal end and about Io $\mathrm{cm}$ from the proximal end. The tube was then removed from the cannula, immediately immersed in water at $38^{\circ}$ and transferred to a constant temperature room also at $38^{\circ}$ where it was suspended vertically. The $10 \mathrm{~cm}$ of tube open to the air was uppermost and was emptied of its contents. This was filled with liquid paraffin and the upper clip removed. The lower end of the tube was connected to about $60 \mathrm{~cm}$ of cellophane tubing $\left(\frac{8}{32}\right.$ in. diameter Visking tubing; Union Carbide Corp.). The remaining clip was opened and the effluent allowed to run through the cellophane tube. The first $10 \mathrm{ml}$ were discarded and the next $\mathrm{I} 0 \mathrm{ml}$ collected for immediate $\mathrm{pH}$ determination and subsequent analysis. The cellophane tubing was tied at the bottom and placed in a glass vessel which was evacuated. The apparatus was then similar to that described by Gregory (1954) with the vertically suspended PVC tube acting as a reservoir. Ultrafiltration was allowed to continue for about $2 \mathrm{~h}$ when the whole sample remaining in the tube (about $40-60 \mathrm{ml}$ ), as well as the ultrafiltrate (about $5^{-15} \mathrm{ml}$ ), was removed for immediate $\mathrm{pH}$ determination and subsequent analysis. In all experiments the total concentrations of $\mathrm{Ca}, \mathrm{Mg}$ and inorganic phosphate, calculated for residual sample plus ultrafiltrate, were close to those in the $10 \mathrm{ml}$ sample collected initially. This indicated that the effluent had a reasonably constant composition along the collecting tube.

In order to study the effect of different factors on the distribution of $\mathrm{Mg}, \mathrm{Ca}$ and inorganic phosphate, it was necessary to make additions to the samples. This in itself involved a departure from in vivo conditions, and for convenience in handling and to reduce the effect of bacterial growth during handling other changes were also made. Some experiments explored the effects of these changes but for comparative purposes, unless otherwise stated, standardized conditions were employed. The procedure adopted, which will be referred to as the 'standard procedure' was as follows.

Ileal effluent samples were freshly thawed after being stored at $-14^{\circ}$. Preliminary experiments with three samples, each from a different ruminating calf, showed no appreciable difference in the proportion of $\mathrm{Mg}$ ultrafilterable at $\mathrm{pH} 6.5$ between samples examined directly after collection without freezing $(74 \pm 3 \%)$ and after I4 weeks storage at $-14^{\circ}(75 \pm 3 \%)$. Ca ultrafilterability showed a small fall from $68 \pm 3 \%$ for the fresh samples to $61 \pm 3 \%$ for the stored samples. The samples were homogenized in an Ato-Mix blender (Measuring and Scientific Equipment Ltd) and strained through surgical gauze. A known weight of the strained material was brought to $\mathrm{pH}_{5} .5$ by adding $0.5 \mathrm{~N}-\mathrm{HCl}$ in $0.25 \mathrm{M}-\mathrm{NaCl}$ with a stream of nitrogen bubbling through the mixture. In this way bicarbonate ions were replaced by chloride ions. The $\mathrm{pH}$ 
was then brought to the desired value by adding either $0.25 \mathrm{~N}-\mathrm{NaOH}$ (carbonate-free) or $0.5 \mathrm{~N}-\mathrm{HCl}$ in $0.25 \mathrm{M}-\mathrm{NaCl}$. The mixture was made up to nearly twice the original sample weight with $0.25 \mathrm{M}-\mathrm{NaCl}$ and shaken in a water-bath at $27^{\circ}$ for $\mathrm{Ih}$. The $\mathrm{pH}$ was readjusted if necessary and the mixture made exactly twice the original sample weight with $0.25 \mathrm{M}-\mathrm{NaCl}$ and shaken for a further hour. No further appreciable change in $\mathrm{pH}$ occurred and preliminary experiments at $\mathrm{pH} 2.5,5.5,6.5$ and 8.0 showed that no change in distribution of $\mathrm{Ca}, \mathrm{Mg}$ or inorganic phosphate occurred during the 2 nd hour. 'There was no change in the total amount of inorganic phosphate during $2 \mathrm{~h}$ incubation at $\mathrm{pH} 2 \cdot 5,5 \cdot 5,6 \cdot 5$ or $8 \cdot 0$, suggesting the absence of appreciable amounts of organic phosphorus compounds labile under these conditions. The mixture was then centrifuged at $27^{\circ}$ at $35000 \mathrm{~g}$ for $30 \mathrm{~min}$. The supernatant fraction was usually ultrafiltered for $4 \mathrm{~h}$ also at $27^{\circ}$, cellophane tubing as described above being used in the apparatus described by Gregory (1954).

The choice of ionic strength for the solutions added to ileal effluent in the above procedure requires some explanation. The ionic strength of ileal effluent is variable and difficult to derive with any accuracy, but sodium, potassium, chloride and bicarbonate ions provide the biggest contribution, about $0.12-0 . I_{4}$ for effluent after a milk feed (Smith, I966) and about $0.15^{-O}$ I $_{7}$ for effluent from ruminating calves (our unpublished observations). To this must be added a variable contribution from $\mathrm{Mg}$, $\mathrm{Ca}$ and inorganic phosphate which can only be deduced by making assumptions. In milk-fed calves the $\mathrm{Ca}$ in ileal contents appears to be mainly bound (Smith, I966) and the relatively small amount of inorganic phosphate is probably present largely as insoluble calcium phosphates. $\mathrm{Mg}$, on the other hand, is probably largely ionic (Smith, I966) and, if this is so, calculation shows that $\mathrm{Mg}$ and associated anions contribute about $0.05-0.10$ to the ionic strength. In ruminating calves, if ultrafilterable $\mathrm{Ca}, \mathrm{Mg}$ and inorganic phosphate are assumed to be ionic, calculation from the values in Table 2 suggests a contribution to the ionic strength of about $0^{\circ} 0_{3}-0 \cdot 05$. These figures would be reduced if any of the ultrafilterable or osmotically active (Smith, I966) forms of these constituents were not ionic but bearing in mind the probability of a small contribution from other ions (e.g. ammonium) and the reciprocal relationship between $\mathrm{Mg}$ and $\mathrm{Na}+\mathrm{K}$ concentrations in ileal effluent after a milk feed (Smith, I966), a reasonable estimate puts the ionic strength between about 0.20 and 0.25 for both ruminating and non-ruminating calves. Thus to maintain fairly constant conditions and, as far as possible, to simulate the ionic strength existing in vivo, dilutions were carried out with solutions of ionic strength 0.25 . Ions provided by hydrochloric acid were not taken into account since these mainly led to the loss of equivalent amounts of bicarbonate ions.

To summarize: in the standard procedure samples were diluted with an equal volume of fluid, they were examined at $27^{\circ}$ and were allowed $2 \mathrm{~h}$ to equilibrate at this dilution and temperature. The ionic strength was maintained at about 0.25 .

A slightly different procedure was used when the effects of altering the concentration of $\mathrm{Mg}$ or $\mathrm{Ca}$ were examined (see Figs. 3 and 4 ). To achieve a suitably high concentration of the appropriate ion it was necessary to add it in an amount which raised the ionic strength above 0.25 . The mixture to which the greatest amounts were added 
had an ionic strength of about 0.38 and all the mixtures used in these experiments were adjusted to about this value by adding sodium chloride where necessary. Similarly, to adjust the $\mathrm{pH}$ with as little dilution as possible in experiments to examine the effect of dilution (see Fig. 5), it was necessary to add sodium hydroxide solution with an ionic strength much higher than 0.25 giving an ionic strength in the mixture of about 0.30 . This value was used in all these experiments.

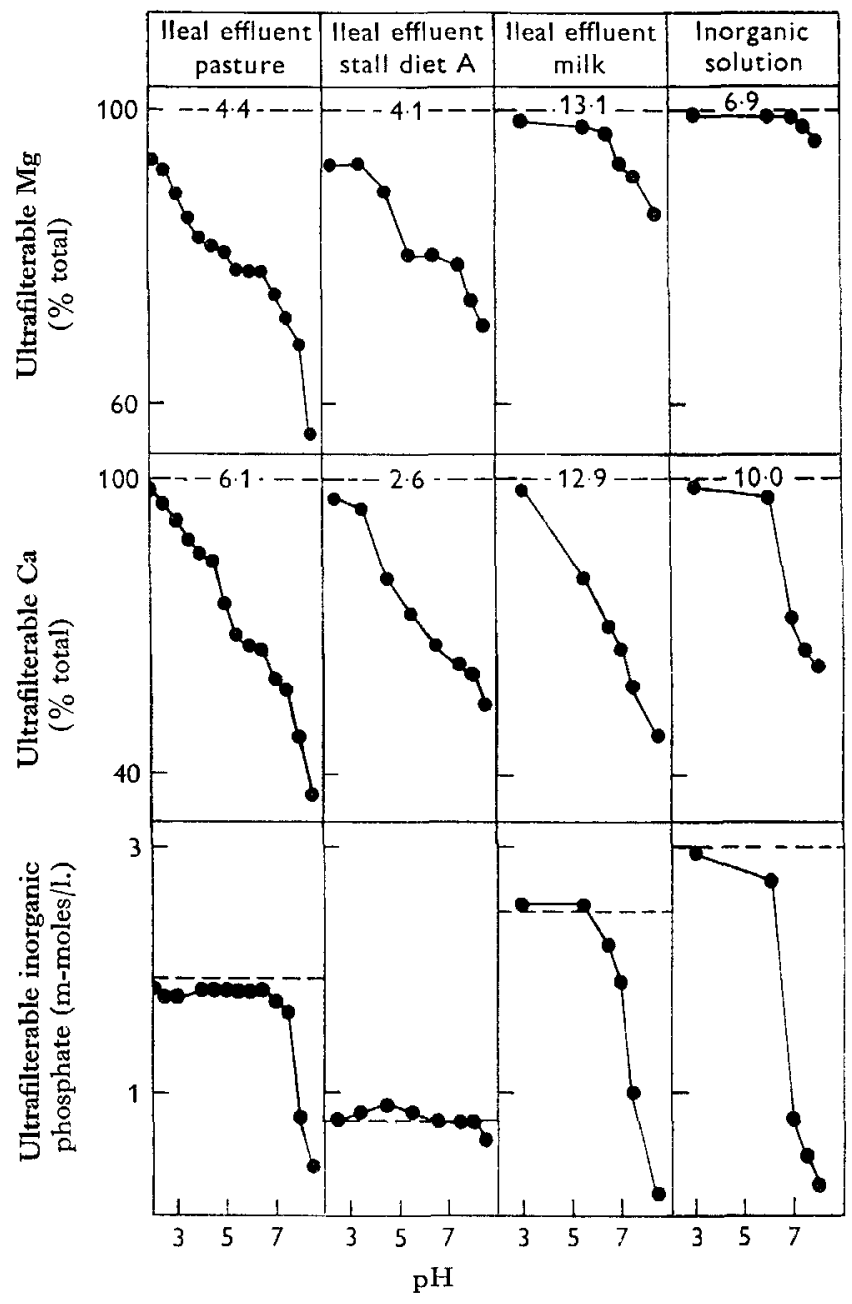

Fig. I. Amounts of ultrafilterable magnesium, calcium and inorganic phosphate at different $\mathrm{pH}$ values in samples of ileal effluent from calves given different diets examined by the standard procedure (see p. 706) and in an inorganic solution of similar ionic strength (for details see p. 7 IO). Ultrafilterable $\mathrm{Ca}$ and $\mathrm{Mg}$ are expressed as percentages of the total concentrations, which are shown in absolute terms (m-moles/1.) by figures on each graph. All inorganic phosphate values are shown as absolute concentrations, the totals being shown by appropriately placed horizontal broken lines. All absolute values are for the final mixtures, i.e. the effluent samples diluted with approximately equal volumes of solutions of ionic strength 0.25 . The composition of the stall diet is described on p. 704 . 


\section{RESULTS}

\section{Ultrafilterability of $\mathrm{Ca}, \mathrm{Mg}$ and inorganic phosphate}

when the standard procedure was used

Effect of $p H$ and phosphate concentration. The change in distribution of $\mathrm{Ca}, \mathrm{Mg}$ and inorganic phosphate over a range of $\mathrm{pH}$ values varying between about $2 \cdot 0$ and 8.5 was examined in four, six and nine ileal effluent samples from milk-fed calves, stall-fed calves (diet A, see p. 704) and calves grazing spring pasture, respectively. Examples are shown in Fig. I. The samples varied considerably in their $\mathrm{Ca}, \mathrm{Mg}$ and inorganic phosphate contents. The respective ranges were $4-35,5-33$ and $1 \cdot 2-$

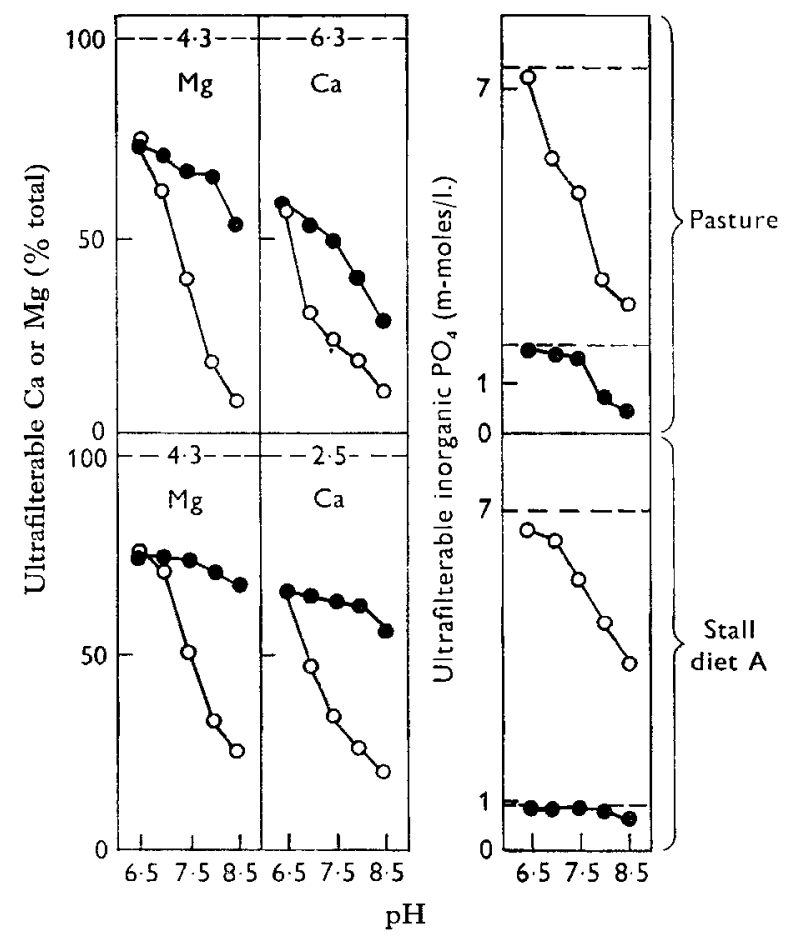

Fig. 2. Amounts of ultrafilterable magnesium, calcium and inorganic phosphate at different $\mathrm{pH}$ values in samples of ileal effluent from calves given different diets with $(O)$ and without ( ) the addition to the samples of solutions of inorganic phosphate $\left(\mathrm{KH}_{2} \mathrm{PO}_{4} / \mathrm{K}_{2} \mathrm{HPO}_{4}\right)$. All were examined by the standard procedure (see p. 706). Values are represented in the same way as in Fig. 1 , absolute values again being for the final mixtures. The composition of the stall diet is described on p. 704 .

$20 \mathrm{~m}$-moles $/ \mathrm{l}$. for the ruminating calves and $13-31,26-79$ and $\mathrm{I} \cdot 3-5 \cdot 7 \mathrm{~m}$-moles $/ 1$. for the milk-fed calves. Nevertheless certain features in common, exemplified in Fig. I, were observed. At $\mathrm{pH} 2-3$ all or nearly all the $\mathrm{Ca}, \mathrm{Mg}$ and inorganic phosphate was ultrafilterable. For samples from the ruminating calves there was a marked progressive decrease in the amounts of ultrafilterable $\mathrm{Ca}$ and $\mathrm{Mg}$ with increasing $\mathrm{pH}$ up to about 5.5 although inorganic phosphate remained completely ultrafilterable. Above this 
$\mathrm{pH}, \mathrm{Mg}$ ultrafilterability usually did not change appreciably and $\mathrm{Ca}$ ultrafilterability changed less rapidly than before, until inorganic phosphate ultrafilterability also began to decrease. The $\mathrm{pH}$ at which this occurred varied from sample to sample and appeared to depend broadly on the phosphate content. Extreme values were about 6.5 and 8.5 for the extreme ileal effluent inorganic phosphate concentrations of 20 and $\mathrm{I} \cdot 2 \mathrm{~m}$-moles/l. respectively. The addition of extra phosphate to other samples (the ionic strength being kept at about 0.25 ) led to the formation of non-ultrafilterable inorganic phosphate at the lower $\mathrm{pH}$ (Fig. 2). A marked fall in ultrafilterable $\mathrm{Ca}$ accompanied the fall in ultrafilterable inorganic phosphate (e.g. pasture effluent in Fig. I) and the addition of phosphate magnified the effect (Fig. 2). Ca and inorganic phosphate were also both rendered partly non-ultrafilterable above about $\mathrm{pH}^{6-7}$ in samples of an inorganic solution containing $0.02 \mathrm{M}-\mathrm{CaCl}_{2}, 0.013 \mathrm{M}-\mathrm{MgCl}_{2}$ and $0.006 \mathrm{M}$ phosphate buffer $\left(\mathrm{NaH}_{2} \mathrm{PO}_{4} / \mathrm{H}_{3} \mathrm{PO}_{4}\right.$ to give $\left.\mathrm{pH} 3\right)$ which, at $27^{\circ}$, were adjusted to different $\mathrm{pH}$ values and an ionic strength of 0.25 by adding equal volumes of solutions containing suitable amounts of $\mathrm{NaOH}$ or $\mathrm{NaCl}$ or of both. $\mathrm{Ca}$ and inorganic phosphate were rendered non-ultrafilterable in the molar ratio of about $\mathrm{I} \cdot 4: \mathrm{I}$. This was presumably the composition of the calcium phosphate salt precipitated (cf. Boulet, Marier \& Rose, 1962). Appreciable formation of non-ultrafilterable Mg did not occur in this inorganic solution up to $\mathrm{pH} 8.0$ and this finding was equally true when $\mathrm{Ca}$ was omitted from the mixture and the inorganic phosphate concentration increased to $18 \mathrm{~m}$-moles $/ 1$. In mixtures containing ileal effluent from ruminating calves, on the other hand; ultrafilterable $\mathrm{Mg}$ sometimes decreased markedly as the $\mathrm{pH}$ was raised to above $65^{-7} 7^{\circ}$. The effect was most marked for samples with the highest inorganic phosphate concentrations and was usually greatly increased in other samples (five out of six experiments) on the addition of extra phosphate (Fig. 2). Although it has often been suggested that $\mathrm{Mg}$ might be precipitated in the gut as magnesium ammonium phosphate there appears to be little information on the concentration of ammonium ions in the ileum. Van Weerden (1961) reported a mean value of about $20 \mathrm{~m}$-moles/l. in adult cattle, and in eight samples of ileal effluent from five ruminating calves receiving either pasture or stall diets we found values from 4 to $16 \mathrm{~m}$-moles $/ \mathrm{l}$. When the inorganic solution experiment illustrated in Fig. I was repeated with the addition of $5 \mathrm{~m}$-moles ammonium chloride/l., the ultrafilterable $\mathrm{Mg}$ was reduced by $\mathrm{O}, 6, \mathrm{II}$ and $\mathrm{I} 4 \%$ at $\mathrm{pH} 6,7,7.5$ and 8 respectively. This effect was qualitatively similar to that shown in some samples of ileal effluent from ruminating calves.

For mixtures prepared from samples of ileal effluent from milk-fed calves an increase in $\mathrm{pH}$ from about 2 to 5.5 led to a marked fall in $\mathrm{Ca}$ ultrafilterability but that of $\mathrm{Mg}$, as well as of inorganic phosphate, fell very little. With further increase in $\mathrm{pH}$, inorganic phosphate, $\mathrm{Ca}$ and sometimes $\mathrm{Mg}$ ultrafilterability decreased in a manner similar to that shown by the samples from ruminating animals.

Effect of diet. The experiments described above and illustrated in Fig. I showed a marked difference in the pattern of $\mathrm{Mg}$ ultrafilterability in samples of ileal effluent from ruminating calves, on the one hand, and from milk-fed non-ruminating calves on the other. They did not however indicate any qualitative differences between ileal 
effluents with the two different solid diets. To explore the possibility of quantitative differences between results with these and with other diets under conditions in which phosphate precipitation was unimportant, further samples of ileal effluent were collected from calves given various diets and examined at $\mathrm{pH} 5.5$ or $6 \cdot 5$. The milk-fed calves used were 2-3 months of age and were given 4.40-6. I 5 1. milk/day, sometimes with supplementary $\mathrm{Mg}\left(\mathrm{I} \cdot 6 \mathrm{~g} /\right.$ day as chloride). The ruminating calves were $2 \frac{1}{2}-7$ months of age and received either pasture or one of the stall diets described on p. 704 . Results are summarized in Table r. Except for $\mathrm{Mg}$ values with the milk diet, there were no significant differences in mean percentage ultrafilterability for $\mathrm{Mg}$ or $\mathrm{Ca}$ between the different diets examined. The rather low values for non-ultrafilterable $\mathrm{Mg}$ on diets $F$ and $G$ were each obtained with only one calf which gave similarly low values ( 20 and $14 \%$ respectively) with diets $\mathrm{D}$ and $\mathrm{E}$. Variation between calves was considerably greater than that within calves.

Table I. Total magnesium, calcium and inorganic phosphate concentrations in ileal effluent from calves receiving different diets and the percentages of these minerals which were non-ultrafilterable when the samples were adjusted to different $p H$ values, the standard procedure (see p. 7o6) being used

Ileal effluent

\begin{tabular}{|c|c|c|c|c|c|c|c|c|}
\hline \multirow[b]{2}{*}{ Diet } & \multirow{2}{*}{$\begin{array}{l}\text { No, of } \\
\text { calves } \\
\text { exam- } \\
\text { ined }\end{array}$} & \multicolumn{3}{|c|}{$\begin{array}{l}\text { Range in total concentration } \\
\text { (m-moles } / 1 .)\end{array}$} & \multirow[b]{2}{*}{$\begin{array}{l}\text { Examined } \\
\text { at } \mathrm{pH}\end{array}$} & \multicolumn{3}{|c|}{ Mean non-ultrafilterable ( $\%$ total) } \\
\hline & & $\mathrm{Mg}$ & $\mathrm{Ca}$ & $\begin{array}{c}\text { Inorganic } \\
\mathrm{PO}_{4}\end{array}$ & & $\mathrm{Mg}$ & $\mathrm{Ca}$ & $\begin{array}{c}\text { Inorganic } \\
\mathrm{PO}_{4}\end{array}$ \\
\hline Milk & 5 & $27-79$ & I $4-33$ & $-)$ & \multirow{8}{*}{$5 \cdot 5$} & $(4 \pm 2 \cdot 6$ & $25 \pm 5 \cdot 0$ & - \\
\hline Pasture & 5 & $1 I-22$ & $8-23$ & -1 & & $23 \pm 2 \cdot 6$ & $3 I \pm 5.0$ & - \\
\hline Stall: B & 5 & $6-9$ & $4-9$ & - & & $29 \pm 2 \cdot 6$ & $37 \pm 5 \cdot 0$ & - \\
\hline $\mathrm{C}$ & I & 22 & Io & - & & $27 \pm 5.8$ & $3^{6 \pm} \pm \mathrm{I} \cdot 2$ & - \\
\hline $\mathrm{D}$ & 3 & $9-16$ & $9-20$ & - & & $25 \pm 3 \cdot 3$ & $40 \pm 6 \cdot 5$ & - \\
\hline$E$ & 4 & $8-13$ & $7^{-20}$ & $\cdots$ & & $22 \pm 2 \cdot 9$ & $3 I \pm 5 \cdot 6$ & 一 \\
\hline $\mathrm{F}$ & I & 24 & 25 & - & & $14 \pm 5.8$ & $32 \pm I I \cdot 2$ & - \\
\hline G & I & 4 & 4 & -1 & & $l_{17 \pm 5.8}$ & $26 \pm I I \cdot 2$ & - \\
\hline Milk & 5 & $27-79$ & $14-33$ & $I-6)$ & \multirow{6}{*}{$6 \cdot 5$} & $(x 7 \pm 2 \cdot 2$ & $40 \pm 5 \cdot 3$ & $28 \pm 8.8$ \\
\hline Pasture & 5 & $10-x 7$ & $10-37$ & $3^{-1} 3$ & & $30 \pm 2 \cdot 2$ & $4^{6} \pm 5 \cdot 3$ & $3 I \pm 8.8$ \\
\hline Stall: A & 6 & $8-15$ & IO- 35 & $3-13$ & & $26 \pm 2 \cdot 0$ & $33 \pm 4 \cdot 8$ & II $\pm I \cdot 7$ \\
\hline $\mathrm{C}$ & 2 & $18-21$ & I4-19 & $1-5$ & & $28 \pm 3.5$ & $3^{8} \pm 8 \cdot 4$ & $11 \pm 2.9$ \\
\hline D & 2 & $9-10$ & $9-12$ & $2-26$ & & $36 \pm 3.5$ & $50 \pm 8 \cdot 4$ & $9 \pm 2.9$ \\
\hline $\mathrm{E}$ & 3 & $8-13$ & $7-18$ & $4-14)$ & & $29 \pm 2 \cdot 9$ & $43 \pm 6.8$ & $8 \pm 2 \cdot 4$ \\
\hline
\end{tabular}

Maximum, minimum and mean values were derived from calf mean values which were usually based on observations on from two to four different samples per calf.

Standard errors for $\mathrm{Mg}(\%)$ and $\mathrm{Ca}(\%)$ mean values were based on the pooled variation between means for calves within diets and have $\mathrm{r} 7 \mathrm{df}$; but for inorganic $\mathrm{PO}_{4}(\%)$ pooling of variation was limited and the SEs for milk and pasture means have $8 \mathrm{df}$ and those for the stall diets $9 \mathrm{df}$.

Inorganic phosphate was almost completely ultrafilterable at $\mathrm{pH}_{5.5}$ in all the samples. Details of the stall diets are given on p. 704 .

The above results were all for calves established on the appropriate diet for a period of at least $\mathrm{I}$ week. For three calves collections were also made only 2 days after a changeover from stall diet $\mathrm{B}$ to pasture. Proportions of non-ultrafilterable $\mathrm{Mg}$ and $\mathrm{Ca}$ at $\mathrm{pH} 5.5$ were not markedly different; mean values after 2 days on pasture were $30 \pm 5 \%$ and $39 \pm 5 \%$ for $\mathrm{Mg}$ and $\mathrm{Ca}$ respectively. 
Effect of $M g$ and $C$ a concentrations. An attempt was made, by suitable supplementation, to keep $\mathrm{Mg}$ and $\mathrm{Ca}$ intakes on the stall diets roughly the same. The mean concentrations of these constituents in ileal effluent did not therefore usually differ too widely for these diets and were also of the same order during pasture feeding (Table I). Nevertheless there were sometimes very considerable variations in individual samples even on the same diet.

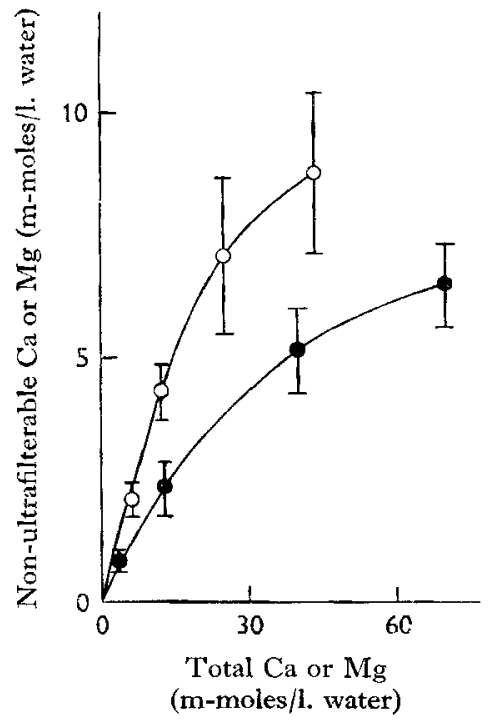

Fig. 3

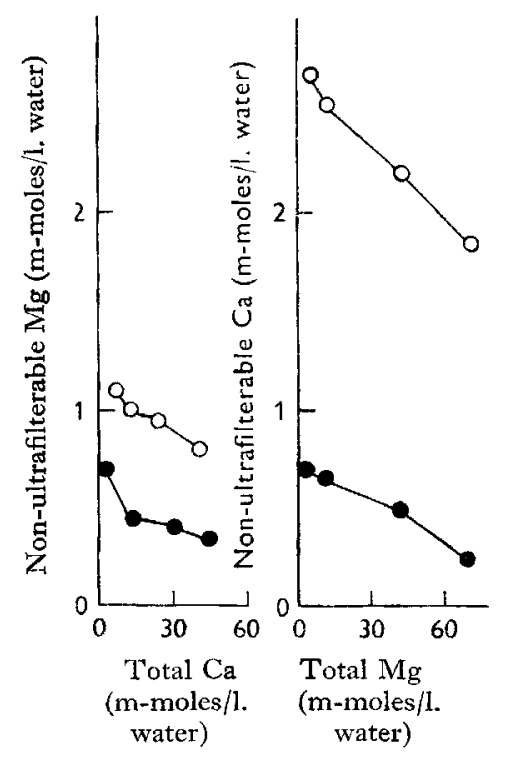

Fig. 4

Fig. 3. Effect of total calcium concentration on non-ultrafilterable $\mathrm{Ca}(\mathrm{O})$ and of total magnesium concentration on non-ultrafilterable $\mathrm{Mg}(\bullet)$ in samples of ileal effluent from ruminating calves, at $\mathrm{pH} 5 \cdot 5-6 \cdot 0$. Each value shown is a mean for four experiments with different samples, two from calves fed on diet A (see p. 704) and two from calves grazing pasture. Standard errors of the means are indicated by vertical bars. The lowest mean value shown for each metal is for the unsupplemented samples, the remainder for the samples containing various added amounts of solutions of $\mathrm{CaCl}_{2}$ or $\mathrm{MgCl}_{2}$. Except that dilutions were all made with solutions of ionic strength $0.5 \circ$ (see p. 707), the samples were examined by the standard procedure (see p. 706) and values relate to the final mixtures.

Fig. 4. Effect of total calcium concentration on non-ultrafilterable magnesium and of total $\mathrm{Mg}$ concentration on non-ultrafilterable $\mathrm{Ca}$ in samples of ileal effluent from ruminating calves at $\mathrm{pH} 6 \cdot 0$. For each effect values are shown for a sample from a calf fed on diet $A$ (see p. 704) $(0)$, and from a calf grazing pasture $(O)$. The lowest total value for each curve is for the unsupplemented sample, the remaining values are for the same sample containing various added amounts of solutions of $\mathrm{CaCl}_{2}$ or $\mathrm{MgCl}_{2}$. Except that dilutions were all made with solutions of ionic strength 0.50 (see p. 707 ), the samples were examined by the standard procedure (see p. 706 ) and values relate to the final mixtures.

The possible effect of such variations was examined by adding calcium or magnesium chloride to samples of ileal effluent. The results in Fig. 3 show that at $\mathrm{pH} 5 \cdot 5^{-6} \mathrm{O}$ (negligible phosphate precipitation) additional amounts of $\mathrm{Ca}$ or $\mathrm{Mg}$ were rendered partly non-ultrafilterable but in decreasing proportions as the amounts added increased; presumably as the binding material tended to become saturated. Moderate additions however were rendered non-ultrafilterable in about the same proportions as in the 
original samples. The results in Fig. 4 show further that the addition of $\mathrm{Ca}$ increased the proportion of ultrafilterable $\mathrm{Mg}$ and vice versa.

These facts must be borne in mind in assessing the binding power of any particular sample on the basis of the proportions of $\mathrm{Ca}$ or $\mathrm{Mg}$ rendered non-ultrafilterable. In individual samples considerable differences could be introduced by the wide variations in absolute and relative concentrations of $\mathrm{Ca}$ and $\mathrm{Mg}$, but for the mean values given in Table $\mathrm{I}$ it appears that variations were not generally sufficient to invalidate comparison between diets. Furthermore, $\mathrm{Mg}$ and $\mathrm{Ca}$ concentrations were sufficiently alike to demonstrate unequivocally a greater binding power for $\mathrm{Ca}$ than for $\mathrm{Mg}$ at $\mathrm{pH} 5_{5} \cdot 6 \cdot 5$. The results in Table $\mathrm{I}$ show that, with the solid diets, at $\mathrm{pH} 5.5$ percentage Ca binding was, as a mean effect, $I^{\cdot} 5 \pm 0 \cdot 2$ times that of $\mathrm{Mg}$. Extrapolation of the curves in Fig. 3 suggests also that, at saturation, the binding material accepted more $\mathrm{Ca}$ than it $\operatorname{did} \mathrm{Mg}$.

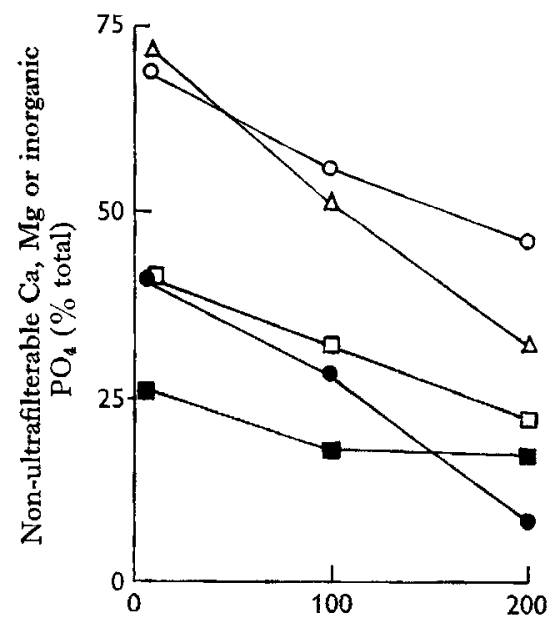

Diluting fluid added (\% ileal effluent)

Fig. 5. Effect of the degree of dilution on the percentages of calcium $(O, \bullet)$, magnesium $(\square, \square)$ and inorganic phosphate $(\triangle)$ which were non-ultrafilterable in samples of ileal effluent from a calf grazing pasture examined at $\mathrm{pH} 7.5$ (open symbols) and at $\mathrm{pH} 5.5$ (solid symbols). Except that dilutions were made with solutions calculated to give a final ionic strength in the mixture of about 0.30 (see p. 708), the results for $100 \%$ dilution were obtained by the standard procedure (see p. 706). Apart from the differing degrees of dilution, the other results were obtained in the same way, the final ionic strength always being about 0.30 .

\section{Effect of variation from the standard procedure}

The effects of varying the degree of dilution of samples of ileal effluent from calves grazing pasture, for conditions in which phosphate precipitation occurred $(\mathrm{pH} 7 \cdot 5)$ and did not occur $\left(\mathrm{pH}_{5} \cdot 5\right)$, are illustrated in Fig. 5. With increasing dilution the ultrafilterability of all the constituents increased although there appeared to be little change for $\mathrm{Mg}$ between $\mathrm{I} 00$ and $200 \%$ dilution at $\mathrm{pH} 5.5$. Closely similar behaviour was found when the experiments were repeated with samples from stall-fed (diet A) calves. With the two diets at $\mathrm{pH} 5.5$ the mean differences between no dilution (estimated by extrapolation) and 100\% dilution (standard procedure) in the percentages of non-ultrafilterable $\mathrm{Ca}$ and $\mathrm{Mg}$ respectively were $\mathrm{I} 2 \pm 4$ and $\mathrm{II} \pm 2$. 
The effect of varying the temperature at which the samples were equilibrated, centrifuged and ultrafiltered, but otherwise using the standard procedure, was examined with the samples of ileal effluent from calves given diet $\mathrm{A}$ and pasture for which results at $27^{\circ}$ are given in Fig. I. At pH 6.5 mean results for non-ultrafilterable $\mathrm{Mg}$ and $\mathrm{Ca}$ remained within the ranges $2 \mathrm{I}-25 \%$ and $34-38 \%$ respectively at temperatures of 4,27 and $38^{\circ}$. At $\mathrm{pH} 7 \cdot 5$ ranges were $25-27 \%$ and $41-45 \%$ respectively at temperatures of 27 and $38^{\circ}$. No marked differences were apparent at the different temperatures. Little non-ultrafilterable inorganic phosphate was present in these samples even at $\mathrm{pH} 7.5$ (see Fig. I) so the above results refer essentially to nonphosphate binding.

\section{Ultrafilterability of $\mathrm{Ca}, \mathrm{Mg}$ and phosphate in the distal ileum in vivo}

The $\mathrm{pH}$ of ileal effluent rises rapidly on exposure to air. Samples were collected from ruminating calves without such exposure by clipping each end of the tube connecting ingoing and outgoing cannulas. Examination of such samples showed that, with the exception of effluent obtained after giving diet $\mathrm{F}$ which gave a mean value of $6.95 \pm 0.15$ for three samples from one calf, there was little variation in $\mathrm{pH}$ and no consistent difference between diets. For 134 samples from ten calves eating one of the stall diets (other than diet F) or pasture the mean $\mathrm{pH}$ was 7.66 and the standard deviation of a single determination \pm 0.25 .

Table 2. Properties of ileal effuent from ruminating calves ultrafiltered under conditions approximating to those existing in vivo (see p. 706)

\begin{tabular}{|c|c|c|c|c|c|c|c|c|}
\hline \multirow[b]{3}{*}{ Calf } & \multirow[b]{3}{*}{ Diet } & \multicolumn{7}{|c|}{ Ileal effluent } \\
\hline & & \multicolumn{3}{|c|}{ Total concentration (m-moles $/$.) } & \multicolumn{3}{|c|}{ Non-ultrafilterable (\% total) } & \multirow[b]{2}{*}{$\begin{array}{c}\text { Mean } \\
\mathrm{pH}\end{array}$} \\
\hline & & $\mathrm{Mg}$ & $\mathrm{Ca}$ & $\begin{array}{c}\text { Inorganic } \\
\mathrm{PO}_{4}\end{array}$ & $\mathrm{Mg}$ & $\mathrm{Ca}$ & $\begin{array}{c}\text { Inorganic } \\
\mathrm{PO}_{4}\end{array}$ & \\
\hline \multirow[t]{2}{*}{$5 J$} & Stall diet $\mathrm{D}$ & 10.6 & $17 \cdot 3$ & $2 \cdot 2$ & $4^{8}$ & 63 & NM & $7 \cdot 56$ \\
\hline & Pasture & 143 & $4 I^{\prime} \cdot \mathrm{I}$ & 110 & 35 & 84 & 98 & $7 \cdot 83$ \\
\hline \multirow[t]{2}{*}{$6 \mathrm{~J}$} & Stall diet B & 10.3 & 15.2 & $20 \cdot \mathrm{I}$ & 74 & 92 & NM & $7 \cdot 25$ \\
\hline & Pasture & $19 \cdot 1$ & $25 \cdot 6$ & $9 \cdot 0$ & 35 & 66 & 89 & 7.08 \\
\hline \multirow[t]{2}{*}{$7 \mathrm{~J}$} & Stall diet $\mathrm{E}$ & $9 \cdot \mathbf{I}$ & $24 \cdot 7$ & $24 \cdot 4$ & 60 & 93 & 49 & $7 \cdot 52$ \\
\hline & Pasture & 13.5 & $2 \mathrm{I} \cdot \mathrm{I}$ & $7 \cdot 0$ & 34 & 66 & 89 & $7 \cdot 48$ \\
\hline
\end{tabular}

The $\mathrm{pH}$ values of six samples ultrafiltered under conditions as close as possible to those existing in vivo (see p. 706) were between 7.30 and 7.90 (mean $7.58 \pm 0.10$ ), and therefore within the normal range, at the beginning of the ultrafiltration. The mean fall in $\mathrm{pH}$ during the ultrafiltration was only $0.25 \pm 0.08 \mathrm{pH}$ units. Results for the percentage of $\mathrm{Mg}, \mathrm{Ca}$ and inorganic phosphate which were non-ultrafilterable in these samples are given in Table 2. 


\section{Preliminary observations on the physical state of the non-ultrafilterable $\mathrm{Mg}$ and $\mathrm{Ca}$}

In the experiments described above fractionation was always achieved by ultrafiltration. The cellophane membrane used was largely permeable to polyethylene glycol of molecular weight 1500 and impermeable to polyethylene glycol of molecular weight 6000 . This indicates roughly the upper size limit of molecules in the ultrafiltrates although molecular weight is not the only factor determining the passage of materials through a cellophane membrane (Ryle, 1965). In some experiments the mixtures were alternatively filtered through a Millipore filter (Grade HA; Millipore Filter Corp.) with a mean pore diameter of $0.45 \mu \mathrm{m}$. For sixteen samples from five calves fed on diet $\mathrm{A}$ or pasture and examined at $\mathrm{pH} 5 \cdot 5-6 \cdot 5$ the percentages of total $\mathrm{Ca}$ and $\mathrm{Mg}$ not filterable ( $25 \pm \mathrm{I}$ and $\mathrm{I} 9 \pm 2$ respectively) were respectively $6 \cdot \mathrm{I} \pm 0 \cdot 9$ and $2 \cdot 1 \pm 0.6$ lower than the percentages not ultrafilterable. With three of the calves determinations were made at a range of $\mathrm{pH}$ values from $3-8$ similar to those shown in Fig. I. Changes with $\mathrm{pH}$ in the percentages of total $\mathrm{Mg}$ and $\mathrm{Ca}$ which were filterable paralleled closely the corresponding changes in ultrafilterable $\mathrm{Mg}$ and $\mathrm{Ca}$ but tended throughout to be somewhat higher (by $0-4 \%$ for $\mathrm{Mg}$ and 2-10\% for $\mathrm{Ca}$ ).

In other experiments the slightly opalescent supernatant fraction obtained after centrifuging the mixtures at $35000 \mathrm{~g}$ for $30 \mathrm{~min}$ was analysed. Mean results for sixteen experiments at $\mathrm{pH} 5 \cdot 5-6 \cdot 5$ with five calves fed on diet A or pasture showed $3^{6} \pm 4 \%$ and $72 \pm 5 \%$ of the non-ultrafilterable $\mathrm{Ca}$ and $\mathrm{Mg}$ respectively to be present in this supernatant fraction.

Samples of ileal effluent from two milk-fed calves showed no difference between filterable and ultrafilterable $\mathrm{Ca}$ at $\mathrm{pH} 6 \cdot 5$. Experiments with effluent from four such calves showed only $9 \pm 3 \%$ of the non-ultrafilterable $\mathrm{Ca}$ in the supernatant fraction after centrifuging as above.

\section{DISCUSSION}

It appeared that both $\mathrm{Mg}$ and $\mathrm{Ca}$ were bound (in the sense of being rendered nonultrafilterable) in at least two different ways in the ileal contents of ruminating calves, one depending on the presence of phosphate, the other not.

The nature of the material responsible for the non-phosphate binding is unknown and it probably consists of more than one substance (see p. 716 ). The only indication of the amount present in any particular sample was the extent of the $\mathrm{Mg}$ and $\mathrm{Ca}$ binding when the $\mathrm{pH}$ was made sufficiently low to prevent phosphate precipitation. This was of limited value since the absolute and relative amounts of the two metals present also affected the percentages which were bound, but it was sufficient to show that all the solid diets examined gave rise to amounts of binding material of a similar order. In particular there was no evidence to suggest any marked increase in binding material when the calves went on a diet of spring grass. The fact that material capable of binding $\mathrm{Mg}$ appeared to be characteristic of ruminating calves given a wide variety of diets, although it was absent from non-ruminating calves, suggested that it may have been of microbial origin. Although changes in the total numbers of rumen bacteria with changes in diet have sometimes been reported (e.g. Maki \& Foster, r957), these 
numbers have more often been found to be fairly constant in the long term even with wide dietary variation (e.g. Williams, Nottle, Moir \& Underwood, I953; Wilson \& Briggs, I955).

Non-phosphate binding of $\mathrm{Ca}$ and $\mathrm{Mg}$ in ileal effluent increased with increasing $\mathrm{pH}$ above about $\mathrm{pH}_{2-3}$ but for $\mathrm{Mg}$ appeared to approach a maximum at about $\mathrm{pH}_{5} .5$ and above. Ca binding at $\mathrm{pH}_{5} 5$ was also considerable although not apparently maximal. Therefore, if it is assumed that the binding material is present throughout the small intestine, and the results of Storry $(196 \mathrm{r} b)$ showing material with similar properties in the sheep abomasum support this view, the binding shown in the ileum is probably shown also, though modified by composition differences, in all of that part of the small intestine with a $\mathrm{pH}$ of 5.5 or above. By analogy with sheep (Storry, $196 \mathrm{r} a$ ) and nonruminating calves (our unpublished observations) it is probable that such $\mathrm{pH}$ conditions occur in all of the small intestine except the most proximal duodenum.

Despite the competition between $\mathrm{Mg}$ and $\mathrm{Ca}$ for, at least, part of the binding material, $\mathrm{Ca}$ was, in general, bound more efficiently than $\mathrm{Mg}$ at $\mathrm{pH} 5.5$ and above and there were quantitative differences in the behaviour of the two metals with changes in $\mathrm{pH}$ and dilution. Further, there was a marked difference of distribution for bound $\mathrm{Mg}$ and $\mathrm{Ca}$ respectively between sedimented and suspended fractions after centrifuging. This suggested that the binding material was not a single substance but consisted of, at least, two fractions with different affinities for $\mathrm{Mg}$ and $\mathrm{Ca}$.

In practice, determinations of non-phosphate binding were carried out at about in vivo ionic strength but usually at $27^{\circ}$ and with the samples diluted with an equal volume of fluid. Temperature appeared to be unimportant, but the dilution was shown to depress percentage binding (Fig. 5). Taking this into account it appeared from the values in Table I that about $30-45 \%$ of the $\mathrm{Mg}$ in the ileal contents under in vivo conditions would usually be bound without phosphate. A similar estimate for $\mathrm{Ca}$ was more difficult because non-phosphate calcium binding appeared to increase above $\mathrm{pH} 5.5$. A rough estimate, however, suggested that in vivo something like half the Ca would be bound without phosphate. Samples of ileal effuent containing fairly low concentrations of inorganic phosphate and examined under conditions as close as possible to those existing in vivo (Table 2) showed values for non-ultrafilterable $\mathrm{Mg}$ and $\mathrm{Ca}$ similar to or only slightly greater than these estimated values. In the samples containing high concentrations of phosphate, however, the values were much greater than this for both $\mathrm{Mg}$ and $\mathrm{Ca}$. There was in particular a direct relationship between the concentration of inorganic phosphate and the percentage of non-ultrafilterable $\mathrm{Ca}$. This was in accordance with other experiments showing the effect on $\mathrm{Ca}$ ultrafilterability of adding inorganic phosphate to effluent samples. It appears probable that this was due to precipitation of calcium phosphate and that its extent, at any one $\mathrm{pH}$, was controlled by the activities of the $\mathrm{Ca}$ and relevant phosphate ions, and broadly therefore by the $\mathrm{Ca}$ and phosphate concentrations, in a manner similar to that shown in simple inorganic solutions. The formation of non-ultrafiltrable $\mathrm{Mg}$ dependent on phosphate, which was also demonstrated, could not however be explained in such a simple way. It occurred at about $\mathrm{pH} 6 \cdot 5-7 \cdot 5$ at $\mathrm{Mg}$ and phosphate concentrations which did not lead to magnesium phosphate precipitation in simple inorganic solution, 
and other factors were clearly involved. It is probable that ammonium concentration was one such factor although it is not clear how important this was. If differing ammonium ion concentrations could lead to marked differences in $\mathrm{Mg}$ precipitation a possible mechanism for the apparent association of clinical hypomagnesaemia with ammonia production in the rumen (Head \& Rook, I957) would be suggested. However, our recent unpublished experiments have shown that, in the presence of adequate $\mathrm{Ca}$, $\mathrm{Mg}$ will precipitate with phosphate at $\mathrm{pH} 6 \cdot 5-7 \cdot 5$ whether or not ammonium is present. The extent of $\mathrm{Mg}$ precipitation in this way is thus defined by an interrelated set of factors which requires further study. The available evidence suggests, however, that under the usual conditions found in the ileum the main limiting factor is likely to be phosphate concentration. Reported variations in $\mathrm{Mg}$ and $\mathrm{Ca}$ ultrafilterability in the cow ileum (Head \& Rook, 1957) and solubility in the sheep colon (van't Klooster, 1964) are most likely to have been due to variations in phosphate concentration, particularly as these observations were made on small numbers of samples almost certainly showing elevated $\mathrm{pH}$ values from carbon dioxide loss.

Whatever factors are involved, it appears that any effect of phosphate on $\mathrm{Ca}$ and $\mathrm{Mg}$ precipitation would be shown only in the more distal small intestine where the $\mathrm{pH}$ is greater than about $6 \cdot 5-7 \cdot 0$. This effect may therefore be of less practical importance in limiting $\mathrm{Mg}$ absorption than that of the non-phosphate binding material.

The fact that ileal effluent from milk-fed calves, examined by the standard procedure, showed $\mathrm{Mg}$ to be largely ultrafilterable up to about $\mathrm{pH} 7.5$ agrees with evidence showing that the $\mathrm{Mg}$ in such digesta contributes to the osmotic pressure as if it were ionic (Smith, 1966). Similarly the considerable Ca binding found was in agreement with the observed lack of osmotic effect of $\mathrm{Ca}$. The non-phosphate binding material in milk-fed calves is clearly different from that in ruminating calves, combining as it does with $\mathrm{Ca}$ but not $\mathrm{Mg}$, but its nature is unknown.

We thank Dr A. T. Cowie and Mr S. C. Watson for carrying out all surgical operations and Mr B. D. Lawrence, Miss P. E. Lewis and Miss S. M. Castle for technical assistance. We also thank Mr N. W. Pirie for a supply of leaf protein.

\section{REFERENCES}

Aikawa, J. K. (1959). Proc. Soc. exp. Biol. Med. roo, 293.

Boulet, M., Marier, J. R. \& Rose, D. (1962). Archs Biochem. Biophys. 96, 629.

Care, A. D. \& van't Klooster, A. T. (1965). F. Physiol., Lond. 177, I74.

Chutkow, J. G. (1964). 7. Lab. clin. Med. 63, 71 .

Conway, E. J. (1957). Microdiffusion Analysis and Volumetric Error, 4th ed., p. 98. London: Crosby, Lockwood and Son Ltd.

Field, A. C. (1961). Br. F. Nutr. I5, 349.

Graham, L. A., Caesar, J. J. \& Burgen, A. S. V. (1960). Metabolism 9, 646.

Gregory, M. E. (1954). Br. F. Nutr. 8, 340.

Head, M. J. \& Rook, J. A. F. (1957). Proc. Nutr. Soc. 16, 25.

Maki, L. R. \& Foster, E. M. (1957). F. Dairy Sci. 40, 905.

Morrison, J. E. \& Pirie, N. W. (1961). J. Sci. Fd Agric. 12, I.

Ryle, A. P. (1 965). Nature, Lond. 206, 1256.

Schachter, D. \& Rosen, S. M. (1959). Am. F. Physiol. r96, 357.

Scott, D. (1965). Q. Fl exp. Physiol. 50, 312.

Smith, R. H. (1959). Biochem. F. 7X, 306. 
Smith, R. H. (1962). Biochem. F. 83, I5 I.

Smith, R. H. (1963). Nature, Lond. 198, r61.

Smith, R. H. (1964). Nord. VetMed. 16, suppl. I, p. 143.

Smith, R. H. (1966). F. Physiol., Lond. r83, 532.

Storry, J. E. (1961 a), F. agric. Sci., Camb. 57, 97.

Storty, J. E. (1961 b). F. agric. Sci., Camb. 57, 103.

Todd, J. R. (1 96r). F. agric. Sci., Camb. 57, 35 .

van't Klooster, A. Th. (r964). Tijdschr. Diergeneesk. 89, 1709.

van Werden, E. J. (r96r). F. agric. Sci., Camb. 56, 317 .

Williams, V. J., Nottle, M. C., Moir, R. J. \& Underwood, E. J. (r953). Aust. f. biol. Sci. 6, I42.

Willis, J. B. (1960a). Spectrochim. Acta r6, 259.

Willis, J. B. (1960b). Spectrochim. Acta 16, 273.

Wilson, M. K. \& Briggs, C. A. E. (1955). 7. appl. Bact. 18, 294. 